\title{
Effect of Enzymatic Treatment of Flax on Chemical Composition and the Extent of Fiber Separation
}

\author{
Jana De Prez, ${ }^{\mathrm{a}}$ Aart Willem Van Vuure, ${ }^{\mathrm{b}}$ Jan Ivens, ${ }^{\mathrm{c}}$ Guido Aerts, ${ }^{\mathrm{a}}$ and \\ Ilse Van de Voorde ${ }^{\text {a,* }}$
}

\begin{abstract}
Enzymatic treatment of flax is gaining more interest as a promising alternative for dew retting, which is known for its dependence on weather and climate. Therefore, the effect of enzymatic treatments of flax on the effectiveness of fiber separation from each other and chemical fiber composition was investigated in this study. Chemical composition was determined by a gravimetric method, while ease of separation (in the composites society, the process to obtain natural fibers from the plant is usually defined as extraction) was determined based on the amount of long fibers obtained as well as total time needed to release this fiber fraction, providing necessary insights in the extent to which fibers are loosened from the stem. Flax treatment with pectate lyase and polygalacturonase resulted in purified fibers with a cellulose content of 78 and $79 \% \mathrm{w} / \mathrm{w}$ and promising yield values of 24 and $17 \%$, respectively. Besides these pectinases, xylanase activity also showed high potential for enzymatic retting. Hence, pectate lyase, polygalacturonase, and xylanase are promising enzymes to successfully replace the dew retting process.
\end{abstract}

Keywords: Flax; Enzymatic treatment; Polygalacturonase; Xylanase; Separation efficiency; Extraction

Contact information: a: KU Leuven, Faculty of Engineering Technology, Department of Microbial and Molecular Systems $\left(M^{2} S\right)$, Cluster for Bioengineering Technology (CBeT), Technology Campus Ghent, Gebroeders De Smetstraat 1, 9000 Ghent, Belgium; b: KU Leuven, Faculty of Engineering Technology, Department of Materials Engineering (MTM), Technology Cluster for Materials Technology (TC-MT), Campus Group T, Andreas Vesaliusstraat 13, B-3000 Leuven, Belgium; c: KU Leuven, Faculty of Engineering Technology, Department of Materials Engineering (MTM), Technology Cluster for Materials Technology (TC-MT), Campus De Nayer, De Nayerlaan 5, B-2860 Sint-Katelijne Waver, Belgium;

* Corresponding author: ilse.vandevoorde@ kuleuven.be

\section{INTRODUCTION}

Natural fibers are gaining increased attention as an ecofriendly alternative for glass fibers as reinforcement in composite materials. Natural fibers, such as flax, have high specific mechanical properties, are biorenewable, biodegradable, and highly available (Le Duigou et al. 2011; Van Vuure et al. 2015; Bourmaud et al. 2018; De Prez et al. 2018a). To use flax fibers as reinforcement, fibers need to be separated from the plant stem. Traditionally, dew retting followed by a mechanical separation is performed to release flax fiber bundles from the woody core of the stem. However, the dependence on weather conditions, climate, and the region of dew retting in combination with the long duration of the process lead to inconsistency in the fiber quality, while the additional mechanical post-treatment results in further fiber damage (Summerscales et al. 2010; Speri 2011; Shahid et al. 2016). To ensure consistently high-quality flax fibers for demanding applications such as composites, a well-controlled and efficient retting process is necessary. The enzymatic treatment of flax can address the shortcomings of 
dew retting due to its high specificity of enzymes and the better controllability of the process. Moreover, a less severe mechanical separation will be required afterwards, inducing less fiber damage. The reduced severity of the mechanical processing can increase the yield of long fibers and thus compensate for the extra cost of enzymatic retting.

During retting, flax fibers are loosened and partly separated from the woody stem. After retting, a mechanical separation is necessary to remove the woody parts left on the fiber. Traditionally, the mechanical separation consists of breaking, scutching, and hackling (Bos 2004). With breaking, flax stems are led between fluted rollers to break the woody stem. Scutching is a beating process to separate shives from fibers. Finally, hackling further enhances fineness through a combing process to obtain a higher degree of alignment of the fibers (Bos 2004). However, the mechanical separation implies a lot of fiber damage due to the severity of the several individual processing steps. By the treatment of flax with targeted enzyme preparations, fibers can be removed more easily from the woody stem, implying that a less severe mechanical post-treatment will be necessary, and thus less fiber damage will be induced. Additionally, a higher yield of long fibers will be achieved. Thus, enzymes show a great deal of potential to realize consistent high-quality natural fibers.

Fiber bundles are mainly composed of polysaccharides, with cellulose, hemicellulose, and pectin being the three most important polymers (Akin 2013; De Prez et al. 2018b). Cellulose consists of an unbranched backbone of $\beta$-1,4-linked D-glucose units. The crystalline form of cellulose is accountable for the high mechanical properties of the natural fibers. Hemicellulose is another important polysaccharide present in the fiber and binds to cellulose. The most abundant forms of hemicellulose are xyloglucan and arabinoxylan, both are branched polysaccharides that are more easily degraded compared to cellulose (Cosgrove 2005). Pectins are complex polysaccharides in the surrounding network of cellulose with an interconnecting purpose as well. Examples of common pectic polysaccharides are homogalacturonan, xylogalacturonan, and rhamnogalacturonan I and II (Cosgrove 2005). Other than cellulose, hemicellulose, and pectin, lignin is a complex hydrophobic three-dimensional aromatic network with an amorphous structure and is more present in the woody core of the flax stem (De Prez et al. 2018b).

The loosening and separation of the fibers from the woody core can be realized by affecting the surrounding network of polysaccharides around the fibers with enzymes. More specifically, the degradation of pectin and hemicellulose in the network can be accomplished by pectinases and hemicellulases, respectively. Within the class of pectinases, several activities can be distinguished affecting different kinds of pectic polysaccharides, i.e., polygalacturonase, pectate lyase, pectin lyase, and pectin methylesterase. Hemicellulase activity, like endoxylanase, can degrade the hemicellulose polymers. The description of the different mechanisms of these pectinases and hemicellulases has been discussed in detail by De Prez et al. (2018b). Amorphous cellulose can also be present in the surrounding network. Therefore, cellulase activity, which is able to degrade cellulose, can be beneficial to enhance the separation process. Research is being conducted concerning the development of new cellulases as well (Zhang et al. 2017). However, a too severe degradation of cellulose should be avoided, as it will result in cellulose fibrils of reduced fiber strength. Finally, the presence of laccase activity can be beneficial for degradation of the lignin present in the flax stem. Compared with this study, parallels could be found with studies concerning enzymatic treatment of 
nature biomass for the pulp and paper manufacturing processes (Lin et al. 2018; Nie et al. 2018). The feasibility of enzyme applications has been illustrated in the paper industry by Lin et al. (2018). Enzymes result in a decreasing environmental impact and reduced overall production cost.

Research concerning the effect of the aforementioned enzyme activities on the resulting fiber properties is essential to understand their possible role in the retting process and to obtain insights into which activities are essential (De Prez et al. 2018b). A systematic research approach is needed starting from the individual pure enzyme activities. In this way, targeted enzyme blends can be defined as alternatives for the dew retting process. Within this study, flax was treated with various enzymes, and their efficiency was evaluated through the characterization of the chemical composition of the fibers separated after the enzymatic treatment, along with the determination of the separation efficiency. To the best of the authors' knowledge, this systematic research approach has never been applied by other research groups but will deliver valuable scientific insights for the future development of an enzymatically enhanced separation process for natural fibers.

\section{EXPERIMENTAL}

\section{Materials}

Green flax (GR) of the Amina cultivar from Verhalle (Zulte, Belgium) was harvested in 2015 and kindly provided for this research. Dew retted (DR) flax of the same cultivar was harvested by Verhalle as well (Zulte, Belgium, 2015). FlaxTape (FT) from Lineo (Saint Martin Du Tilleul, France) is a commercially available hackled flax fiber product of an unknown cultivar and was also used in this study.

\section{Methods}

Enzymes and activity assays

Different enzymes were tested for their retting effect on flax. The following pectin degrading enzymes were investigated: Scourzyme L (a pectate lyase) and NS59049 (a pectin lyase), both from Novozymes (Dittingen, Switzerland); Rohapect PTE (a pectin lyase) and Rohapect MPE (a pectin methylesterase, both from AB Enzymes (Darmstadt, Germany); and polygalacturonase from Aspergillus niger (SigmaAldrich/Merck, Darmstadt, Germany). Besides pectinases, the following hemicellulose degrading enzymes were tested: Pulpzyme (an endoxylanase) (Novozymes, Dittingen, Switzerland) and an endoxylanase from Thermomyces lanuginosus (SigmaAldrich/Merck, Darmstadt, Germany). In addition, treatments with laccase (NS26021) and cellulase (Carezyme 1000 L) (both from Novozymes, Kalundborg, Denmark) were included.

Polygalacturonase activity was determined using the 3,5-dinitrosalicylic acid (DNS) method, based on the protocol of Miller (1959). As substrate, $0.2 \% \mathrm{w} / \mathrm{v}$ polygalacturonic acid (89\%; Sigma-Aldrich/Merck, Darmstadt, Germany) in $50 \mathrm{mM}$ acetate buffer was used ( $\mathrm{pH}$ 5.0). A DNS (98\%; Acros Organics, Geel, Belgium) reagent was prepared according to the NREL procedure (Adney and Baker 2008). Standard references were prepared containing 0.2 to $1.0 \mathrm{mg} / \mathrm{mL}$ galacturonic acid (galacturonic acid monohydrate; Sigma-Aldrich/Merck, Darmstadt, Germany), control solution contained $0.5 \mathrm{mg} / \mathrm{ml}$ galacturonic acid. For powder enzymes, a $1 \% \mathrm{w} / \mathrm{v}$ solution of the 
enzyme was made in acetate buffer $(50 \mathrm{mM}, \mathrm{pH} 5.0)$ during $30 \mathrm{~min}$ at room temperature. Test tubes with standards or control were prepared containing $1 \mathrm{~mL}$ acetate buffer $(\mathrm{pH}$ 5.0) and $0.5 \mathrm{~mL}$ standard or control solution. All of the test tubes were preheated for 10 min at $40{ }^{\circ} \mathrm{C}$. Suitable enzyme dilutions were analyzed by adding $0.5 \mathrm{~mL}$ to the preheated test tubes containing a $1 \mathrm{~mL}$ substrate solution. Subsequently, all test tubes were incubated for exactly $30 \mathrm{~min}$ at $40{ }^{\circ} \mathrm{C}$, followed by addition of $4 \mathrm{~mL}$ of DNS reagent to stop the enzymatic reaction. Approximately $0.5 \mathrm{~mL}$ of a standard addition solution of 0.4 $\mathrm{mg} / \mathrm{mL}$ galacturonic acid was added to all test tubes before boiling for exactly $10 \mathrm{~min}$ in a warm water bath at $100{ }^{\circ} \mathrm{C}$. After cooling, $1 \mathrm{~mL}$ of the resulting solution was diluted with $2 \mathrm{~mL}$ of demineralized water, and the absorbance was measured spectrophotometrically at $540 \mathrm{~nm}$ with a Thermo Scientific Nicolet Evolution 100 spectrophotometer (Thermo Fisher Scientific, Asse, Belgium). One polygalacturonase unit (PGU/ml) is defined as the amount of enzyme that catalyzes the conversion to $1 \mu$ mole galacturonic acid per minute at $40{ }^{\circ} \mathrm{C}$.

The total xylanase activity was characterized for all enzymes provided in accordance with the polygalacturonase assay. $1 \% \mathrm{w} / \mathrm{v}$ xylan from beechwood (SigmaAldrich/Merck, Darmstadt, Germany) was used as a substrate and standard reference solutions were prepared with glucose $(\mathrm{D}(+)$-glucose monohydrate; Merck, Darmstadt, Germany) instead of galacturonic acid. One xylanase unit $(\mathrm{XU} / \mathrm{mL})$ is defined as the amount of enzyme that catalyzes the conversion of $1 \mu$ mole xylose per minute at $40{ }^{\circ} \mathrm{C}$.

For the evaluation of cellulase activity, Filter Paper Units (FPU) were determined according to the NREL procedure (Adney and Baker 2008). All above mentioned assays were repeated twice, and the samples were analyzed in triplicate. One FPU is defined as the amount of glucose (in $\mu$ mole) released per minute at $40^{\circ} \mathrm{C}$ by $1 \mathrm{~mL}$ of enzyme.

\section{SEM analysis}

The cross section of a flax stem was visualized using scanning electron microscopy (SEM). Furthermore, morphological properties of the treated fibers were characterized via image analysis with SEM as well. A Philips SEM XL30FEG (Philips, Eindhoven, Netherlands) was applied using a voltage of $10 \mathrm{kV}$. Fiber samples were coated with a thin film of gold/palladium (Oerlikon Balzers, Balzers, Liechtenstein) to enhance electrical conductivity. Afterwards, the samples were stored under vacuum before SEM analysis.

\section{Enzymatic treatment of flax and evaluation of ease of fiber separation}

GR flax was used as starting material. Separated fibers after enzymatic treatments on green flax were compared with the separated fibers of the starting material itself and other reference materials, i.e., fibers separated after water treatment on flax (WATER), manually separated DR and FT.

Enzymatic treatments were performed on whole flax stem segments of $25 \mathrm{~cm}$, which were dried for $24 \mathrm{~h}$ at $105{ }^{\circ} \mathrm{C}$, as described in De Prez et al. (2018a). Approximately $50 \mathrm{~g}$ of flax segments were immersed in $1000 \mathrm{~mL}$ of demineralized water containing $25 \mathrm{mM}$ ethylenediaminetetraacetic acid (EDTA disodium salt dehydrate, VWR International, Leuven, Belgium) ( $\mathrm{pH} 5.0$ ) and $0.30 \% \mathrm{v} / \mathrm{v}$ enzyme, with the exception of polygalacturonase from A. niger $(0.60 \mathrm{v} / \mathrm{v} \%)$. The flax segments were incubated for $24 \mathrm{~h}$ at $40{ }^{\circ} \mathrm{C}$ while shaking horizontally. After enzymatic treatment, flax stems were washed twice in water to remove enzymes and solubles. Then they were dried at $105^{\circ} \mathrm{C}$ for $24 \mathrm{~h}$. 
The separation of fibers from the stem segments was performed as described in De Prez et al. (2018a). As stated earlier, in the composites society, the process to obtain natural fibers from the plant is usually defined as extraction. The $E_{\mathrm{s}}$ value is hence identical to the extraction efficiency (EE) (De Prez et al. (2018a). Manual separation was chosen to exclude other possible side effects of mechanical separation and because of the scale of the experiment. According to this method, the overall separation efficiency $\left(E_{\mathrm{s}}\right)$ can be evaluated by determining the total amount of long fibers separated compared to the total amount of flax stems (fiber efficiency, $E_{f}$ ) and the time needed for the separation of these long fibers (time efficiency, $E_{t}$ ) (De Prez et al. 2018a). Adjusted equations for the calculation of $E_{f}, E_{t}$, and $E_{\mathrm{s}}$ are shown in Eqs. 1 through 3,

$$
\begin{aligned}
& E_{f}=\frac{\text { Amount of long fibers separated }(\mathrm{g})}{\text { Total amount of flax stems }(\mathrm{g})} \\
& E_{t}=\frac{\text { Amount of long fibers separated }(\mathrm{g})}{\text { Time needed for extraction }(\mathrm{min})} * 2 \\
& E_{s}=E_{f} * E_{t}
\end{aligned}
$$

where 'amount of long fibers separated' and 'total amount of flax stems' are expressed in weight ( $\mathrm{g}$ ), and 'time needed for separation' is expressed in minutes (min). The amount of long fibers separated, which is used as basis for calculation of $E_{f}$ and $E_{t}$, is defined as the amount of fibers that exhibit a length greater than $15 \mathrm{~cm}$ after separation. The factor 2 in Eq. 2 is expressed in min.g $\mathrm{g}^{-1}$ and represents $100 \%$ time efficiency if $10 \mathrm{~g}$ fibers were separated during a $20 \mathrm{~min}$ period. The parameters $E_{f}, E_{t}$, and $E_{s}$ offer the possibility to compare different enzymatic treatments.

\section{Chemical characterization of fibers}

The chemical characterization of lignin, hemicellulose, and cellulose content of separated fibers was performed via a gravimetric method. The method was based on procedures described by Bledzki et al. (2008) and Ramadevi et al. (2012). The first step of the gravimetric method was the determination of the extractables content and consisted of a Soxhlet extraction for $5 \mathrm{~h}$ with an ethanol:toluene mixture (1:2) (ethanol Disolol from Chem-Lab, Zedelgem, Belgium; toluene from VWR International, Leuven, Belgium) to remove solubles and waxes. Then, $1 \mathrm{~g}$ of dried flax fiber was applied and weighed in an extraction thimble. After extraction, the fibers were washed with $100 \mathrm{~mL}$ of ethanol and $400 \mathrm{~mL}$ of hot water on a Buchner funnel, dried at $105{ }^{\circ} \mathrm{C}$, and weighed. Approximately $80 \mathrm{mg}$ of residual fiber was subsequently utilized for lignin determination. Then, $3 \mathrm{~mL}$ of $72 \%$ v/v sulfuric acid (96\%; Acros Organics, Geel, Belgium) was added to the residual fiber in a test tube with a screw cap and the mixture was incubated for $1 \mathrm{~h}$ at $30{ }^{\circ} \mathrm{C}$ while stirring. After incubation, $84 \mathrm{~mL}$ of demineralized water was added, and the corresponding mixture was autoclaved for $1 \mathrm{~h}$ at $121{ }^{\circ} \mathrm{C}$. After cooling, the content was filtered into crucibles, washed with $50 \mathrm{~mL}$ of demineralized water, and dried and weighed to determine the lignin content.

The residual fiber remaining after the extraction step was also subjected to the holocellulose determination. After adding $160 \mathrm{~mL}$ of demineralized water, $0.5 \mathrm{~mL}$ of glacial acetic acid (100\%; Merck), and $1.5 \mathrm{~g} \mathrm{NaCl}$ (VWR), the residual fiber was incubated for $1 \mathrm{~h}$ at $75^{\circ} \mathrm{C}$. After $1 \mathrm{~h}, 0.5 \mathrm{~mL}$ of glacial acetic acid and $2.5 \mathrm{~g} \mathrm{NaCl}$ was again added to the flask and repeated two more times. The flask was incubated at $75{ }^{\circ} \mathrm{C}$ for a total incubation time of $3 \mathrm{~h}$. Then the flask was cooled in an ice bath. Residual 
fibers were washed on a Buchner funnel with successively $25 \mathrm{~mL}$ of acetone (GPR Rectapur; VWR International, Leuven, Belgium), $25 \mathrm{~mL}$ of ethanol, and $150 \mathrm{~mL}$ of demineralized water, and they were dried for $24 \mathrm{~h}$ at $105{ }^{\circ} \mathrm{C}$. The resulting residue represents the holocellulose content. Finally, the determination of the cellulose content was performed on the resulting holocellulose residue by incubating the residue for $30 \mathrm{~min}$ at $30{ }^{\circ} \mathrm{C}$ in the presence of a $70 \mathrm{~mL} \mathrm{NaOH}$ solution $(18 \% \mathrm{w} / \mathrm{v})(97 \%$; VWR International, Leuven, Belgium). Incubation was continued for 1 more hour after adding $35 \mathrm{~mL}$ of demineralized water. The remaining residue was then washed on a Buchner funnel with subsequently $100 \mathrm{~mL} \mathrm{NaOH}$ solution of $8.5 \% \mathrm{w} / \mathrm{v}, 200 \mathrm{~mL}$ demineralized water, $15 \mathrm{~mL}$ acetic acid solution of $10 \% \mathrm{w} / \mathrm{v}$, and $200 \mathrm{~mL}$ of demineralized water. After drying and weighing, the cellulose content can be calculated from the remaining part. The hemicellulose content was calculated by subtracting the cellulose from the holocellulose content.

Pectin content was spectrophotometrically determined with 3-phenylphenol (90\%; Acros Organics, Geel, Belgium), and determination was based on methods described by Blumenkrantz and Asboe-Hansen (1973), Filisetti-Cozzi and Carpita (1991), and Wang et al. (2015). Dried fibers were subjected to Soxhlet extraction with $190 \mathrm{~mL}$ of $70 \%$ ethanol for $5 \mathrm{~h}$ to remove waxes, washed with $300 \mathrm{~mL}$ of warm water on a Buchner filter, and dried overnight at $105^{\circ} \mathrm{C}$. Pectin was hydrolyzed from the flax fiber with $10 \mathrm{~mL}$ of $6 \mathrm{M}$ $\mathrm{HCl}$ (37\%; Chem-Lab, Zedelgem, Belgium) for $2 \mathrm{~h}$ at $70{ }^{\circ} \mathrm{C}$. The fibers were washed, and the filtrate was collected and diluted to $200 \mathrm{~mL}$. Galacturonic acid stock solutions in the range of 5 and $75 \mu \mathrm{g} / \mathrm{mL}$ were prepared for calibration. The 3-phenylphenol solution consisted of $0.15 \%$ 3-phenylphenol in $0.5 \% \mathrm{w} / \mathrm{v} \mathrm{NaOH}$ and was kept in the refrigerator for 1 month. Approximately $2.4 \mathrm{~mL}$ of a $0.0125 \mathrm{M}$ sodium tetraborate solution (sodium tetraborate decahydrate 99.5\%; Sigma-Aldrich/Merck, Darmstadt, Germany) in $\mathrm{H}_{2} \mathrm{SO}_{4}$ (96\%; Acros Organics, Geel, Belgium) was added to a $0.4 \mathrm{~mL}$ sample, containing 2 to 30 $\mu \mathrm{g}$ uronic acids, and was cooled in an ice water bath. After vortexing and cooling (30 min), the test tubes were incubated in a warm water bath of $100{ }^{\circ} \mathrm{C}$ for $5 \mathrm{~min}$ and cooled down in ice for $30 \mathrm{~min}$. Next, $40 \mu \mathrm{L} 3$-phenylphenol solution was added and the mixture was vortexed. Absorbances were measured after exactly 3 min at $520 \mathrm{~nm}$ with a Nicolet Evolution 100 spectrophotometer (Thermo Fisher Scientific, Asse, Belgium). The samples without the addition of 3-phenylphenol served as a blank for background correction. All characterizations were repeated twice, and the samples were analyzed in triplicate.

\section{RESULTS AND DISCUSSION}

The enzymes are tested for their effectiveness as retting agents in this study. During retting, flax fibers are loosened and partly separated from the woody stem. With enzymatic retting, polymers in the surrounding network of the fibers are degraded by specific activity of the enzymes, which could serve as an alternative for dew retting. In Fig. 1A, a SEM image is shown of the cross-section of a dew retted flax stem (harvested by Verhalle in France in 2014), illustrating the effect of retting. In Fig. 1B, a more detailed representation is given.

In Fig 1B, flax bundles are located within the sclerenchyma layer or the bast tissue (3), underneath the epidermis (1) and cortex (2). The retting results in a partial to full detachment of fiber bundles from the phloem (4) and xylem tissue (5). 


\section{Determination of Enzyme Activities}

Because a systematic research approach is needed starting from the individual pure enzyme activities, as a first step of the research the enzymes were analyzed to gain clear insights into the activities present in the enzyme formulations. This enabled the correlation of each enzyme activity with the characteristic properties of the separated flax fibers and retting efficiency.
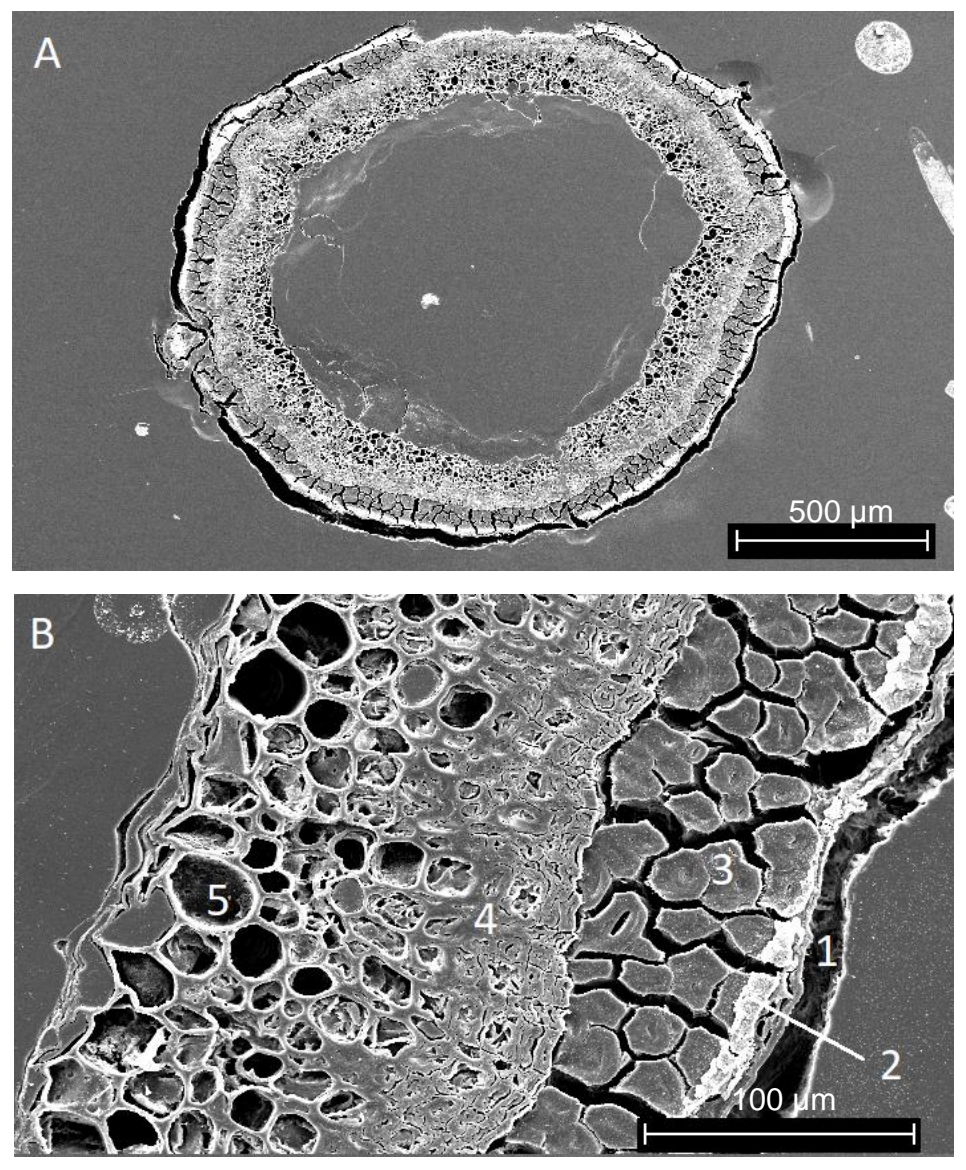

Fig. 1. SEM images of the cross-section of a dew retted flax stem with (A) $50 \times$ magnitude, the scale bar represents $500 \mu \mathrm{m}$ and (B) $350 \times$ magnitude, the scale bar represents $100 \mu \mathrm{m}$; with (1) epidermis, (2) cortex, (3) sclerenchyma or bast tissue, (4) phloem, and (5) xylem 
Table 1. Activities of Enzymes Determined with DNS-method

\begin{tabular}{|c|c|c|c|c|c|}
\hline Enzyme & & Activity & $\begin{array}{l}\text { Polygalactu- } \\
\text { ronase } \\
(\mathrm{PGU} / \mathrm{mL})\end{array}$ & $\begin{array}{c}\text { Xylanase } \\
\text { (XU/mL) }\end{array}$ & $\begin{array}{l}\text { Cellulase } \\
\text { (FPU/mL) }\end{array}$ \\
\hline \multicolumn{6}{|c|}{ Pectinases } \\
\hline Scourzyme L & Sc & Pectate lyase & $0.92 \pm 0.07$ & $0.00 \pm 0.01$ & $0.005 \pm 0.002$ \\
\hline NS59049 & NS & Pectin lyase & $3.06 \pm 0.16$ & $0.12 \pm 0.01$ & $0.015 \pm 0,002$ \\
\hline Rohapect PTE & PTE & Pectin lyase & $1.82 \pm 0.14$ & $18.7 \pm 0.6$ & $0.14 \pm 0.00$ \\
\hline Rohapect MPE & MPE & Pectin methylesterase & $0.05 \pm 0.00$ & $0.29 \pm 0.03$ & $0.02 \pm 0.00$ \\
\hline $\begin{array}{l}\text { Pectinase from } \\
\text { A. niger }{ }^{*}\end{array}$ & PAn & Polygalacturonase & $193 \pm 8$ & $0.78 \pm 0.15$ & $0.02 \pm 0.01$ \\
\hline \multicolumn{6}{|c|}{ Hemicellulases } \\
\hline Pulpzyme & $\mathrm{Pz}$ & Endoxylanase & $1.96 \pm 0.41$ & $2519 \pm 105$ & $0.044 \pm 0.004$ \\
\hline $\begin{array}{l}\text { Xylanase from } \\
\text { T. lanuginosus * }\end{array}$ & XTI & Endo- $\beta-(1,4)$-xylanase & $0.03 \pm 0.01$ & $100.1 \pm 8.0$ & $0.03 \pm 0.00$ \\
\hline \multicolumn{6}{|c|}{ Laccase } \\
\hline NS26021 Laccase & Lac & Laccase & $11.9 \pm 1.3$ & $2.66 \pm 1.5$ & $0.28 \pm 0.14$ \\
\hline \multicolumn{6}{|c|}{ Cellulase } \\
\hline Carezyme $1000 \mathrm{~L}$ & Cel & Cellulase & $0.20 \pm 0.13$ & $0.45 \pm 0.16$ & $1.78 \pm 0.50$ \\
\hline
\end{tabular}

*The pectinase from Aspergillus niger and xylanase from Thermomyces lanuginosus are powder enzymes. For the enzyme assays, solutions of $5 \mathrm{mg} / \mathrm{mL}$ and $10 \mathrm{mg} / \mathrm{mL}$, respectively, were made.

The activity determinations were mainly focused on the determination of polygalacturonase, xylanase, and cellulase activity to gather information about their possible presence as a main or side activity. The results of the enzyme activity assays are presented in Table 1. The enzymes studied are listed according to their main activity.

The results in Table 1 illustrate that among the pectinase enzymes, PAn possessed the highest polygalacturonase activity $(193 \pm 8 \mathrm{PGU} / \mathrm{mL})$. Other pectinase enzymes showed lower to almost no polygalacturonase activity. The mechanisms of the main pectinase activity of Sc, NS, PTE, and MPE were different from the polygalacturonase mechanism although a minor polygalacturonase activity was present in Sc, NS, and PTE. Moreover, a low xylanase and cellulase activity was observed, which was important for the enzymatic treatments. An exception to this was the PTE enzyme, exhibiting a xylanase activity of $18.7 \pm 0.6 \mathrm{XU} / \mathrm{mL}$.

The hemicellulase enzymes, i.e., $\mathrm{Pz}$ and XTl, both showed a high xylanase activity. Polygalacturonase and cellulase activity in the hemicellulase preparations were rather limited. Lac showed a polygalacturonase side activity of $11.9 \pm 1.3 \mathrm{PGU} / \mathrm{L}$ and a minor xylanase activity of $2.66 \pm 1.5 \mathrm{XU} / \mathrm{mL}$. When looking at the activities of Cel, it contained mainly cellulase activity $(1.78 \pm 0.50 \mathrm{FPU} / \mathrm{mL})$. All enzymes listed in Table 1 were then applied for enzymatic treatment of flax to unravel their potential behavior towards the retting process. Subsequently, the separated fibers were chemically characterized.

\section{Chemical Characterization of Flax Fibers}

All enzymatic treatments were effectuated for $24 \mathrm{~h}$ at $40{ }^{\circ} \mathrm{C}$ and a pH level of 5.0, as earlier described. After treatment, fibers were manually separated from the stem for further characterization. 
Table 2. Chemical Characterization of Extracted Flax Fibers After Enzymatic Treatment at pH 5.0 in Comparison with Various Reference Materials

\begin{tabular}{|c|c|c|c|c|}
\hline Treatment & $\begin{array}{c}\text { Cellulose } \\
(\% \mathbf{w} / \mathbf{w})\end{array}$ & $\begin{array}{c}\text { Hemicellulose } \\
(\% \mathbf{w} / \mathbf{w}) \\
\text { References }\end{array}$ & $\begin{array}{c}\text { Lignin } \\
(\% \mathbf{w} / \mathbf{w})\end{array}$ & $\begin{array}{c}\text { Residual Frac. } \\
(\% \mathbf{w} / \mathbf{w})\end{array}$ \\
\hline \multicolumn{5}{|c|}{} \\
\hline GR & $64 \pm 2$ & $13.3 \pm 1.0$ & $4.9 \pm 1.2$ & $18.1 \pm 0.9$ \\
\hline WATER & $71 \pm 3$ & $12.4 \pm 1.2$ & $2.4 \pm 1.1$ & $16.3 \pm 2.0$ \\
\hline DR & $72 \pm 2$ & $9.7 \pm 0.4$ & $3.8 \pm 0.1$ & $14.0 \pm 2.8$ \\
\hline FT & $76 \pm 0$ & $11.7 \pm 0.2$ & $3.3 \pm 0.5$ & $9.2 \pm 0.1$ \\
\hline \multicolumn{5}{|c|}{ Pectinases } \\
\hline Sc & $74 \pm 0$ & $11.7 \pm 0.3$ & $2.5 \pm 0.2$ & $11.7 \pm 0.5$ \\
\hline NS & $76 \pm 0$ & $11.9 \pm 0.7$ & $3.4 \pm 0.2$ & $9.1 \pm 0.7$ \\
\hline PTE & $76 \pm 2$ & $10.8 \pm 0.8$ & $2.7 \pm 0.4$ & $10.7 \pm 1.2$ \\
\hline MPE & $71 \pm 1$ & $12.0 \pm 0.3$ & $3.5 \pm 0.1$ & $13.4 \pm 0.8$ \\
\hline PAn & $77 \pm 2$ & $11.3 \pm 0.7$ & $3.5 \pm 1.0$ & $7.7 \pm 1.1$ \\
\hline Pz & $71 \pm 1$ & $12.2 \pm 0.1$ & $4.3 \pm 0.5$ & $12.1 \pm 1.1$ \\
\hline XTI & $76 \pm 1$ & $11.4 \pm 0.4$ & $2.4 \pm 0.5$ & $10.3 \pm 0.8$ \\
\hline \multicolumn{5}{|c|}{ Laccase } \\
\hline Lac & $69 \pm 1$ & $10.4 \pm 0.4$ & $3.0 \pm 1.0$ & $17.6 \pm 0.2$ \\
\hline \multicolumn{5}{|c|}{ Cellulase } \\
\hline Cel & $74 \pm 1$ & $11.7 \pm 0.2$ & $5.2 \pm 0.8$ & $8.8 \pm 1.1$ \\
\hline
\end{tabular}

To evaluate the effect of the enzymes towards their retting behavior, the chemical composition of the separated flax fibers after enzymatic treatment of green flax was characterized. For comparison, reference materials were included. As reference materials, fibers from GR (the starting material), DR (traditionally retted flax), water treated flax (with tap water at $40{ }^{\circ} \mathrm{C}$ for $24 \mathrm{~h}$ ), and FT fibers (commercially processed flax fibers) were applied. The chemical composition was determined according to the gravimetric method. The cellulose, hemicellulose, and lignin contents of the reference materials and enzymatically separated fibers are shown in Table 2 .

The cellulose content of the untreated flax fibers ranges in the literature from 43 to $65 \%$ w/w, depending on the variety and cultivar (Akin et al. 1996; Akin 2013; George et al. 2016; De Prez et al. 2018b). For the green flax fiber utilized in this research, a cellulose content of $64 \pm 2 \%$ w/w was assessed, which was in accordance with the results from the literature. Water treatment had already resulted in some purification and delivered fibers with a cellulose content of $71 \pm 3 \% \mathrm{w} / \mathrm{w}$. The current retting standard, i.e., dew retting, resulted in purification of the fibers to a cellulose content of $72 \pm 2 \%$ $\mathrm{w} / \mathrm{w}$ and yielded fibers with the lowest hemicellulose content of $9.7 \pm 0.5 \% \mathrm{w} / \mathrm{w}$. The lignin content of water $(2.4 \pm 1.1 \% \mathrm{w} / \mathrm{w})$ and dew retted fibers $(3.8 \pm 0.1 \% \mathrm{w} / \mathrm{w})$ were reduced as well compared to the green fibers $(4.9 \pm 1.2 \% \mathrm{w} / \mathrm{w})$. The rest fractions of the GR and WATER fibers were high, which implied that many impurities were left on the flax stems and fibers after treatment. FlaxTape represented dew retted flax fibers of an unknown cultivar that were additionally mechanically separated and further processed with a hackling step to acquire the alignment and separation of the fibers. This additional processing led to fibers with a cellulose content of $76 \pm 0 \% \mathrm{w} / \mathrm{w}$ and a low rest fraction of $9.2 \pm 0.1 \% \mathrm{w} / \mathrm{w}$. 
Enzymatic treatments clearly led to purified fibers. Pectinase and hemicellulase treatments are expected to affect the surrounding network of the flax fiber (De Prez et al. 2018 b). Flax treated with pectinase enzymes resulted in fibers composed of 71 to $77 \%$ w/w cellulose. The smaller effect observed after MPE treatment can be explained by the lack of degradation of the surrounding network of the fiber, since MPE only removes methyl groups from the pectic backbone. Hence, the pectic backbone and the surrounding network stay intact. The PAn treatment resulted in fibers with the highest cellulose content $(77 \pm 2 \% \mathrm{w} / \mathrm{w})$, illustrating the importance of pectinases, especially polygalacturonase, as enzyme activity for retting. The importance of polygalacturonase for retting natural fibers like flax has also been addressed by Zhang et al. (2000). The hemicellulose and lignin content of the fibers seemed to stay similar among all of the fibers treated with pectinases, but did show a decrease compared to the green fibers (13.1 $\pm 0.2 \% \mathrm{w} / \mathrm{w}$ hemicellulose and $4.9 \pm 1.7 \% \mathrm{w} / \mathrm{w}$ lignin). The rest fraction decreased compared to the reference materials, with the exception of FlaxTape. A low rest fraction usually indicates a good enzymatic treatment, where unwanted components such as waxes have been eliminated during the treatment.

The hemicellulase treatments led to an equal improvement in the cellulose content compared to pectinases, with an XTl treatment resulting in a cellulose content of $76 \pm 1 \%$ $\mathrm{w} / \mathrm{w}$. The Pz treatment showed a smaller increase of cellulose content $(71 \pm 1 \% \mathrm{w} / \mathrm{w})$, and the lignin content did not diminish as much as it did for other treatments compared to the green fibers. The Lac treatment resulted in a decrease in the lignin content but did not achieve the same effect as pectinase and hemicellulase treatments on the cellulose and rest fraction content. This was explained by the lower presence of lignin in the surrounding network of the fiber. Finally, the Cel treatment produced fibers with a cellulose content of $74 \pm 1 \% \mathrm{w} / \mathrm{w}$. As stated in De Prez et al. (2018b), the utilization of cellulase activity in a retting formulation should be carefully considered. Cellulase activity can be beneficial when acting on amorphous cellulose surrounding the network of the fiber, resulting in the loosening of hemicellulose and cellulose also present in the network. However, when interacting on the crystalline cellulosic fiber, cellulase activity can impair the strength of the fiber.

Based on the chemical composition overview of enzymatically separated fibers, polygalacturonase, pectate lyase, pectin lyase, and endoxylanase showed the most promising behavior for the treatment of flax.

Other research groups also investigated the effect of polygalacturonase on flax fibers for the retting efficiency. However, to the best of the authors' knowledge, only a few performed a compositional analysis of the fiber after enzymatic treatment (Akin et al. 1997; George et al. 2016). Akin et al. (1997) tested commercially available enzyme mixtures (Flaxzyme, Ultrazym (both Novo Nordisk, Bagsvaerd, Denmark) and an enriched pectinase mixture (Genencor International, Rochester, NY, USA)) and performed a gas chromatography analysis to determine the chemical composition. The glucose content of enzymatically treated fibers was found to be from 49.0 to $69.9 \% \mathrm{w} / \mathrm{w}$ starting from an un-retted material of $43.4 \% \mathrm{w} / \mathrm{w}$ glucose. George et al. (2016) tested polygalacturonase and xylanase treatment on already isolated fibers during a shorter treatment time of $90 \mathrm{~min}$. Polygalacturonase treatment resulted in fibers of $80.26 \%$ cellulose, $3.34 \%$ hemicellulose, $1.87 \%$ lignin, and $1.36 \%$ pectin. A similar cellulose content was found for the fibers after polygalacturonase treatment in this study $(77 \pm 2 \%$ w/w). In this study, enzymatic treatments were applied on flax stems and not on isolated fibers, which made a direct comparison difficult. 


\section{Separation Efficiency}

Besides the evaluation of the effect of the enzymes on the chemical composition of the separated fibers, it was also important to evaluate the ease of fiber separation after enzymatic retting by determination of the $E_{\mathrm{s}}$ value. The fibers were manually separated, making it possible to solely evaluate the effect of the enzymes. Additional changes in properties from further mechanical treatment that may induce further damage to the fibers, are hence excluded. The results of the separation efficiencies for all of the enzymes studied are illustrated in Fig. 2 and compared to the reference materials.

The results of Fig. 2 illustrate that with respect to the reference materials, the GR and water-treated fibers resulted in a similar $E_{\mathrm{s}}$ value of 11 and $10 \%$, respectively. Dew retted fibers exhibited a remarkably higher $E_{\mathrm{s}}(16 \%)$ compared to the green fibers. Dew retting resulted in the loosening of the fibers from the woody stem, resulting in an easier fiber separation and thus a higher efficiency. For calculation of the $E_{\mathrm{s}}$ for DR fibers, a $E_{\mathrm{f}}$ value of $47 \%$ was observed. The $E_{f}$ value amounted to 34 to $38 \%$ for GR, water, and all enzymatically treated fibers. Minor differences were observed in the total amount of long fibers treated with the different enzymatic conditions. The $E_{\mathrm{s}}$ was hence more influenced by the time needed to isolate the total amount of long fibers.

Among the pectinase enzymes, Sc, NS, and MPE treatment delivered fibers with a low $E_{\mathrm{s}}$ of 5 to $7 \%$. The low $E_{\mathrm{s}}$ was caused by a low $E_{t}$, which meant that the fibers were not sufficiently separated from the woody core. However, the PTE and PAn treatment resulted in fibers that were separated with an efficiency of $11 \%$, which was comparable to GR fibers but still lower than DR fibers and implied insufficient enzyme activity was present or another enzyme activity was needed.

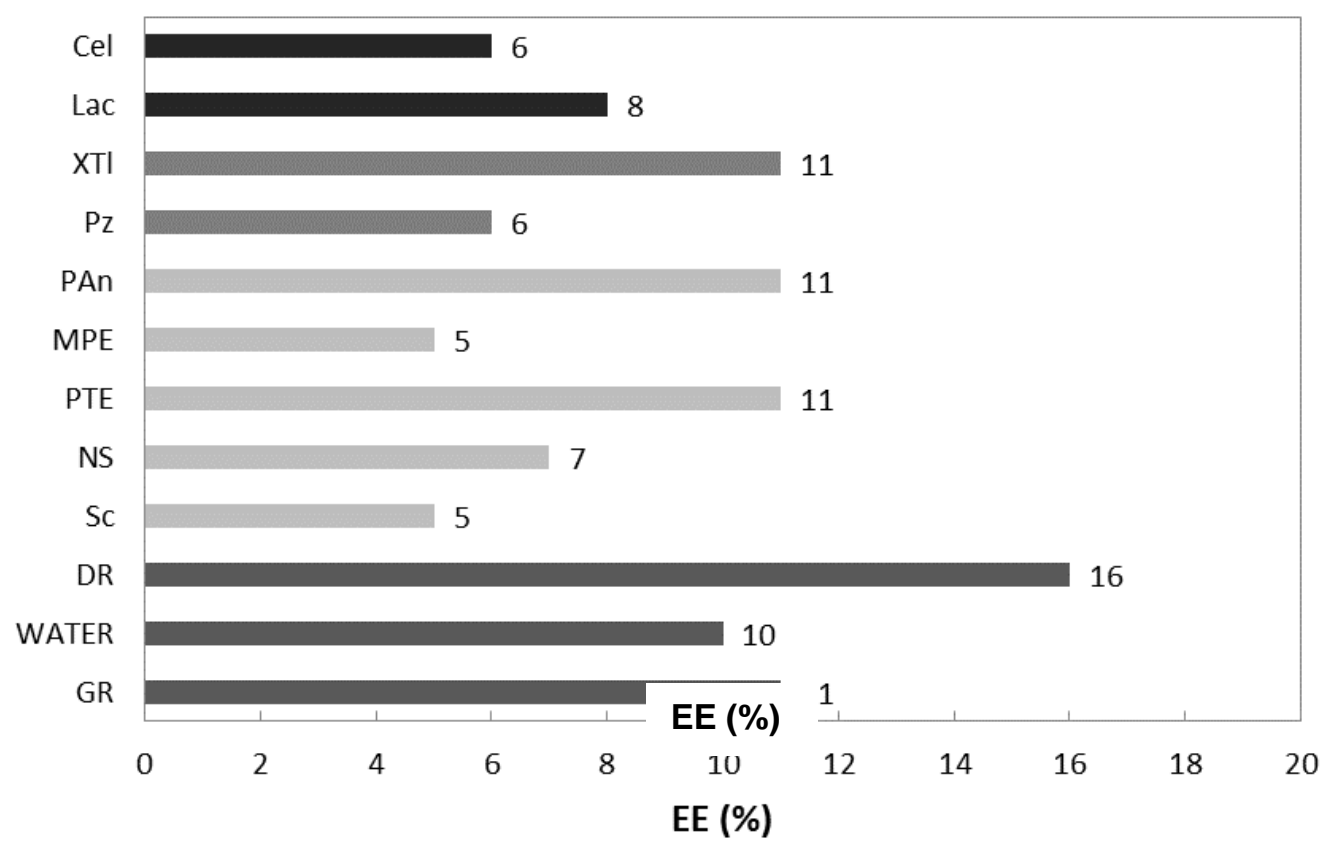

Fig. 2. Separation efficiency of the fibers after enzymatic treatments of flax stems at pH 5.0 
For the hemicellulase enzymes, a low $E_{\mathrm{s}}$ of $6 \%$ was observed for the fibers separated after $\mathrm{Pz}$ treatment, while XTl treatment resulted in fibers with an $E_{\mathrm{s}}$ value of $11 \%$. A higher $E_{\mathrm{s}}$ value of XTl treatment corresponded with the improved results of the characterization of the chemical composition. Finally, compared to the green fibers, the Lac and Cel treatments did not improve the $E_{\mathrm{s}}$. The degradation of lignin does not lead to the degradation of the surrounding network of the fiber, hence no improved separation could be expected.

Treatment with PTE, PAn, and XTl enzymes resulted in fibers that can be separated with the same efficiency as green fibers, which is still low in an industrial context. According to the chemical characterization of the fibers, Sc, NS, PAn, and XTl resulted in the most enhanced chemical composition of the fiber. The PAn and XTl treatments clearly showed an improved separation efficiency as well and thus showed the most potential for the enzymatic retting of flax. However, as an alternative for dew retting, enzymatic treatments should result in fibers with a separation efficiency similar or higher compared to DR fibers. Therefore, some additional enzymatic treatments were investigated.

\section{Effect of pH on Chemical Composition of Separated Flax Fibers and Separation Efficiency}

The enzymatic treatments with the most pectinases and hemicellulases were repeated at a $\mathrm{pH}$ level of 6.5. All other conditions remained unchanged. The PTE enzyme was not included for further testing due to the presence of xylanase activity in the enzyme preparation. Neither were Lac and Cel. Moreover, an additional reference treatment with solely EDTA $(25 \mathrm{mM})$ was performed to gain insight into the contribution of EDTA towards the ease of loosening fibers from the stem. The EDTA treatment was effectuated for $24 \mathrm{~h}$ at $40{ }^{\circ} \mathrm{C}$ and at a $\mathrm{pH}$ level of 6.5 . For the treatments at a $\mathrm{pH}$ of 6.5 , the pectin content was determined in addition to the cellulose, hemicellulose, and lignin contents. The results of the chemical characterization are included in Table 3.

The reference materials of Table 2 are included in Table 3 for comparison with the enzymatic treatments at a $\mathrm{pH}$ of 6.5 . The additional reference treatment performed with EDTA $(25 \mathrm{mM}, \mathrm{pH} 6.5)$ resulted in fibers with a similar cellulose content as fibers after water treatment. Green fibers were composed of $6.1 \% \mathrm{w} / \mathrm{w}$ pectin and were in accordance with pectin contents of flax fibers reported in the literature (Sfiligoj Smole et al. 2013; Wang et al. 2015). Water treatment resulted in a small decrease in the pectin content of the fiber $(5.5 \pm 0.2 \% \mathrm{w} / \mathrm{w})$ compared to the green fibers. The EDTA treatment also resulted in fibers with a lower pectin content $(2.5 \pm 0.3 \% \mathrm{w} / \mathrm{w})$, clearly illustrating the importance of EDTA on the degrading pectin polymers. EDTA is able to chelate $\mathrm{Ca}^{2+}$ out of the pectin structure, thus breaking the calcium bridges between the pectin polymers (Cosgrove 2005; Voragen et al. 2009; Latorre 2014). Consequently, enzymatic retting can be enhanced by the addition of EDTA to the retting formulation. For this reason, all enzymatic treatments were performed in the presence of $25 \mathrm{mM}$ EDTA. 
Table 3. Chemical Characterization of Separated Fibers after Enzymatic Treatment at pH 6.5 in Comparison with Various Reference Materials

\begin{tabular}{|c|c|c|c|c|c|}
\hline Treatment & $\begin{array}{c}\text { Cellulose } \\
(\% \mathbf{w} / \mathbf{w})\end{array}$ & $\begin{array}{c}\text { Hemicellulose } \\
(\% \mathbf{w} / \mathbf{w})\end{array}$ & $\begin{array}{c}\text { Lignin } \\
(\% \mathbf{w} / \mathbf{w})\end{array}$ & $\begin{array}{c}\text { Pectin } \\
(\% \mathbf{w} / \mathbf{w})\end{array}$ & $\begin{array}{c}\text { Rest Fraction } \\
(\% \mathbf{w} / \mathbf{w})\end{array}$ \\
\hline \multicolumn{7}{|c|}{ References } \\
\hline GR & $64 \pm 2$ & $13.3 \pm 1.0$ & $4.9 \pm 1.2$ & $6.1 \pm 0.4$ & $12.0 \pm 0.9$ \\
\hline WATER & $71 \pm 3$ & $12.4 \pm 1.2$ & $2.4 \pm 1.1$ & $5.5 \pm 0.2$ & $8.8 \pm 2.0$ \\
\hline EDTA & $70 \pm 2$ & $12.4 \pm 0.3$ & $6.1 \pm 2.3$ & $2.5 \pm 0.3$ & $9.0 \pm 3.4$ \\
\hline DR & $72 \pm 2$ & $9.7 \pm 0.4$ & $3.8 \pm 0.1$ & $4.0 \pm 0.1$ & $10.0 \pm 2.8$ \\
\hline FT & $76 \pm 0$ & $11.7 \pm 0.2$ & $3.3 \pm 0.5$ & $2.9 \pm 0.1$ & $6.3 \pm 0.1$ \\
\hline \multicolumn{5}{|c|}{ Pectinases } \\
\hline Sc & $78 \pm 1$ & $10.7 \pm 0.4$ & $2.9 \pm 0.3$ & $3.3 \pm 0.6$ & $5.4 \pm 1.1$ \\
\hline NS & $79 \pm 1$ & $9.2 \pm 1.6$ & $3.0 \pm 0.8$ & $2.9 \pm 0.4$ & $5.9 \pm 1.5$ \\
\hline MPE & $78 \pm 2$ & $11.0 \pm 0.7$ & $2.4 \pm 0.5$ & $3.0 \pm 0.0$ & $5.9 \pm 2.3$ \\
\hline PAn & $79 \pm 2$ & $11.5 \pm 0.8$ & $3.5 \pm 1.1$ & $2.8 \pm 0.2$ & $3.6 \pm 1.3$ \\
\hline \multicolumn{7}{|c|}{ Hemicellulases } \\
\hline Pz & $80 \pm 1$ & $10.8 \pm 0.6$ & $2.8 \pm 0.8$ & $3.2 \pm 0.2$ & $3.2 \pm 1.9$ \\
\hline XTI & $80 \pm 1$ & $9.4 \pm 0.0$ & $3.3 \pm 1.1$ & $3.0 \pm 0.3$ & $4.5 \pm 0.0$ \\
\hline
\end{tabular}

Pectinase treatments executed at a $\mathrm{pH}$ level of 6.5 resulted in fibers with an increased cellulose content of 78 to $79 \%$, compared with 71 to $77 \%$ after treatments at a $\mathrm{pH}$ level of 5.0. For all of the pectinase treatments, a small reduction was observed in the hemicellulose and lignin content compared to the green fibers. The residual fractions of the fibers after the pectinase treatment were markedly lower compared to the reference materials. The highest reduction in the rest fraction was observed after the PAn treatment. The low rest fraction implied a highly purified fiber with lower impurities.

Hemicellulases also performed better at a $\mathrm{pH}$ of 6.5 , resulting in fibers with a cellulose content of $80 \pm 1 \% \mathrm{w} / \mathrm{w}$ and lower hemicellulose, lignin, and pectin contents compared to green fibers. The pectin content of fibers after enzymatic treatments were comparable with the pectin content of FlaxTape and of fibers separated after EDTA treatment. All of the enzymatic treatments resulted in more chemically purified fibers while effectuated at a $\mathrm{pH}$ of 6.5 .

The effect of the increase in $\mathrm{pH}$ on the separation efficiency is shown in Fig. 3. The figure clearly illustrates that the increase in $\mathrm{pH}$ to 6.5 improved the separation efficiency of all fibers after the enzymatic treatment. Treatment with Sc, PAn, and XTl resulted in fibers that were separated with the highest efficiency, i.e., with an $E_{\mathrm{s}}$ value of $24 \pm 4 \%, 17 \pm 5 \%$, and $21 \pm 4 \%$, respectively. The EDTA treatment resulted in fibers separated with an $E_{\mathrm{s}}$ value of $18 \pm 3 \%$ (results not shown) and dew retting in an $E_{\mathrm{s}}$ of 16 $\pm 3 \%$ (see Fig. 2). Hence, enzymatic treatments at a pH of 6.5 certainly led to promising separation efficiencies compared to dew retting. A higher $E_{\mathrm{s}}$ will have an impact on the mechanical post-treatment which can be kept limited when fibers are more easily released from the woody core. Hence, less additional damage will be induced which will lead to a more qualitative fiber and higher yield. To the best of the authors' knowledge, other research groups have never reported such separation efficiencies. 


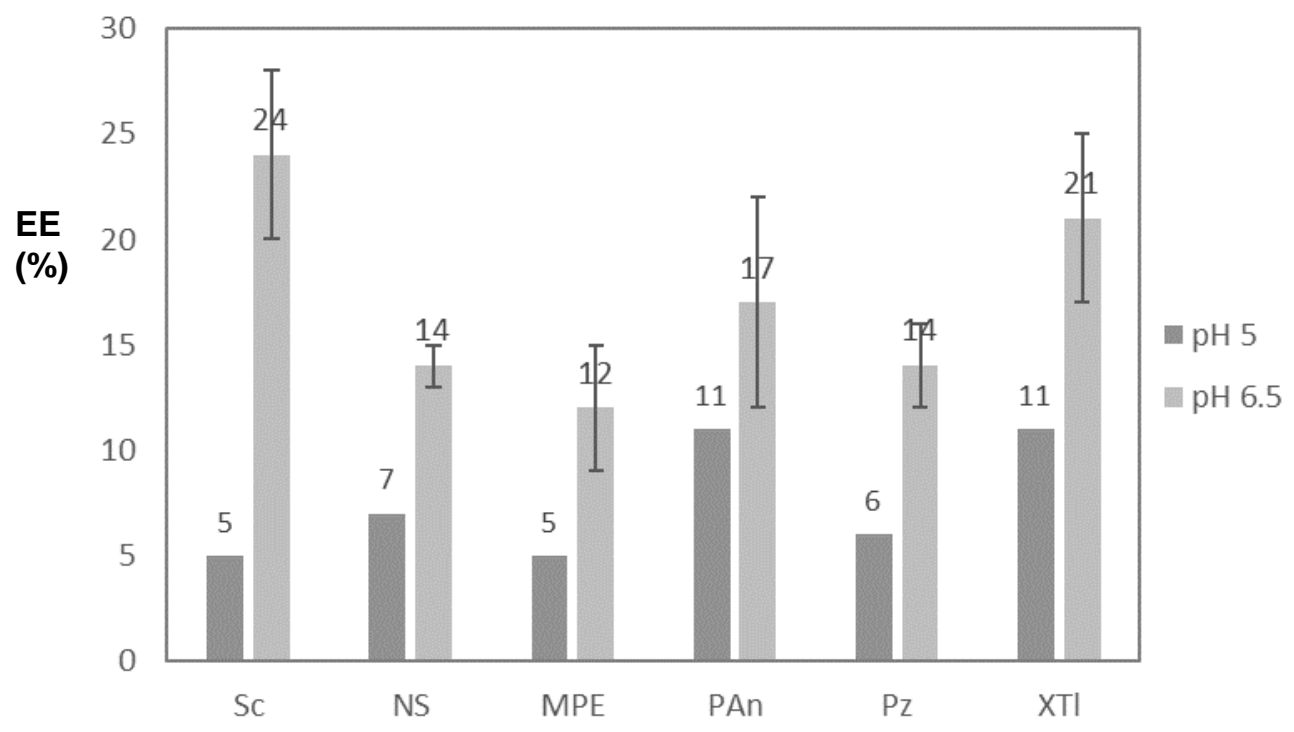

Fig. 3. Comparison of the fiber separation efficiency after enzymatic treatments of flax at $\mathrm{pH} 5$ and $\mathrm{pH} 6.5$

In earlier work it has been observed that the combination of pectate lyase and chelator could lead to the inactivation of the enzyme (Akin et al. 2007). For this reason, Sc treatment was repeated without the addition of $25 \mathrm{mM}$ EDTA, at a $\mathrm{pH}$ of 6.5. However, the chemical composition of the fiber showed no changes of any kind by omitting EDTA $(74 \pm 1 \%$ cellulose, $11.9 \pm 0.1 \%$ hemicellulose, $3.4 \pm 0.6 \%$ lignin and $10.3 \pm 0.5 \%$ residual fraction), while the $E_{\mathrm{s}}$ value dropped to $6 \%$, addressing also the importance of EDTA for enzymatic retting. Additionally, more tests at a higher temperature of $50{ }^{\circ} \mathrm{C}$ were performed with $\mathrm{Sc}$, which was closer to the temperature optimum of the enzyme. Again, no improvement in chemical properties or $E_{\mathrm{s}}$ was observed for the Sc treatment. Hence, the Sc performed most optimally at $40{ }^{\circ} \mathrm{C}$ and in combination with $25 \mathrm{mM}$ EDTA.

\section{Morphological Characterization of Separated Fibers}

To visualize the effect of enzymatic treatments, the fibers separated from flax stems were also morphologically analyzed via SEM. Figure 4 illustrates the reference materials green flax fibers (Fig. 4A) and dew retted fibers (Fig. 4B).

Fig. 4A shows the technical fiber bundles of green flax. Numerous impurities were distinguishable on the fiber surface. Furthermore, compact fiber bundles could be observed for green fibers with no space between individual fibers, indicating minimal retting has taken place in these fiber bundles. 


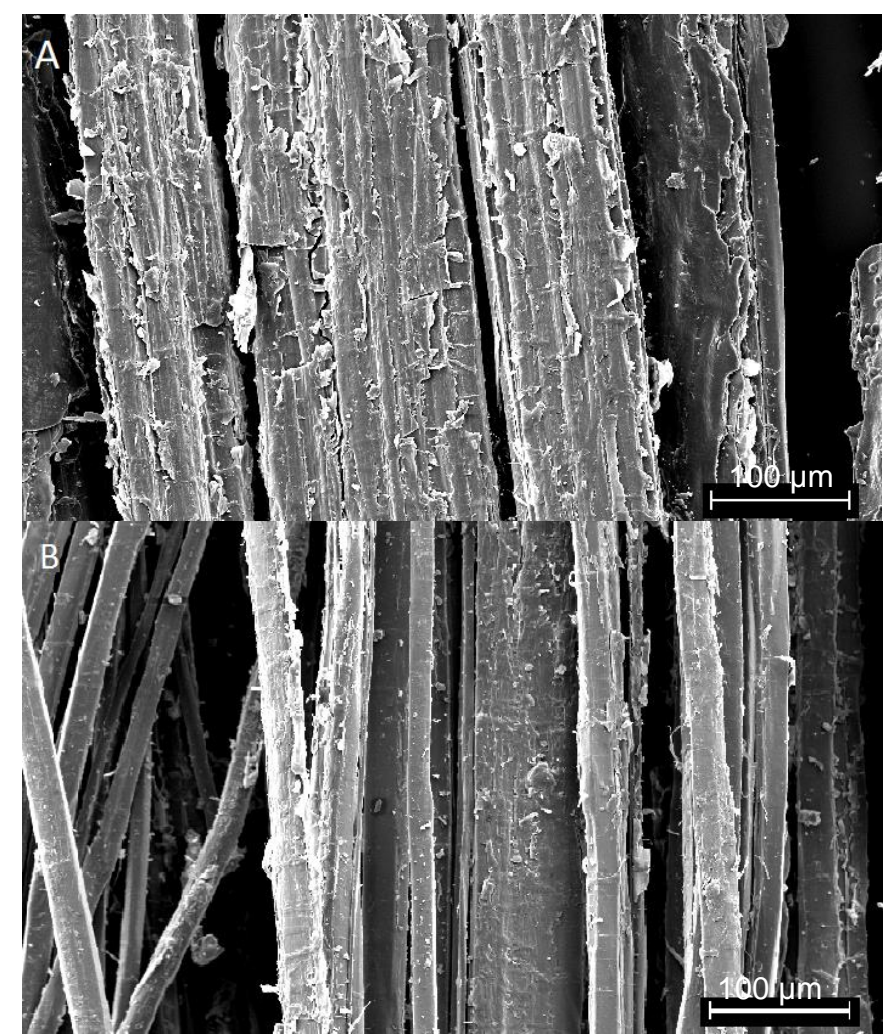

Fig. 4. SEM images of (A) green flax fibers (200x) and (B) DR fibers (200x); the scale bar represents $100 \mu \mathrm{m}$

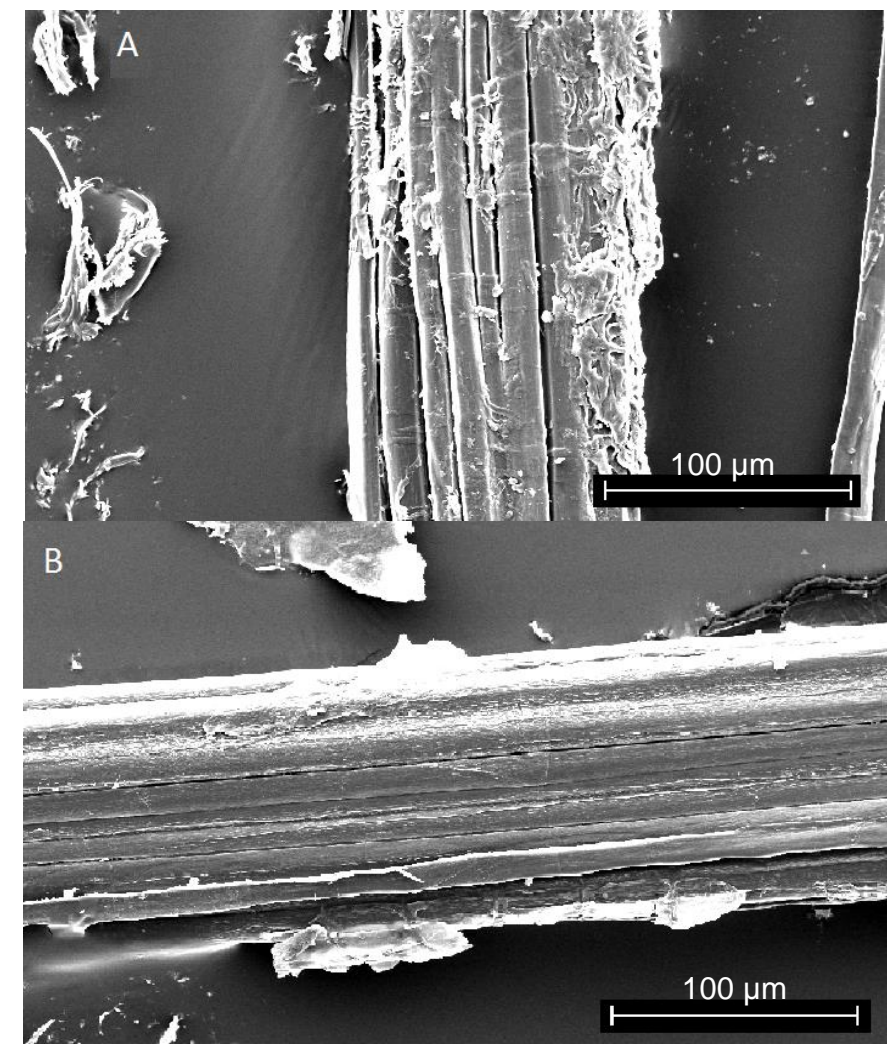

Fig. 5. SEM images of (A) FT (350x) and (B) flax fibers after treatment with Pz (350x); the scale bar represents $100 \mu \mathrm{m}$ 
In contrast, the DR fibers (Fig. 4B) clearly possessed a reduced amount of impurities on the fiber surface and exhibited more separation between the elementary fibers. Results of SEM analysis of FT fibers and enzymatically treated fibers are shown in Fig. 5. As an illustration of enzymatic treatments, the SEM analysis on fibers after $\mathrm{Pz}$ treatment is shown in Fig. 5B.

FT fibers (Fig. 5A) exhibited a clean fiber surface. Within the fiber bundles, a certain loosening can be observed between the elementary fibers. The higher degree of loosening between individual fibers illustrates that fibers were retted more extensively. It should be taken into account however that mechanical manipulation of DR and FT fibers also further increased fiber separation. Finally, Fig. 5B is an illustration of enzymatic treatments, and fibers after the Pz treatment are shown. The fiber surface was cleaner and almost no impurities were present on the surface. Although the fiber bundle seems still coherent, some loosening of fibers within the fiber bundle was observed. Hence, enzymatic treatment had a clear effect on the surrounding network of the fiber.

The results of this study showed that enzymatic treatment can be a worthy alternative for dew retting. Taking into account both the chemical composition and separation efficiency, important enzyme activities to realize enzymatic retting are pectate lyase (Sc), polygalacturonase (PAn), and xylanase (XTl), resulting in the highest $E_{\mathrm{s}}$ values and in more chemically pure fibers. The other enzymes studied also showed potential but may be important, not as individual enzymes but in combination with other enzyme activities. For instance, MPE can probably be more successful when combined with other enzymes, as a complementary enzyme for pectate lyase to degrade pectin structures. Therefore, the study of strategic combinations of different enzyme activities is important for future research concerning enzymatic treatments as an alternative for dew retting.

Moreover, for the efficient utilization of enzymatically treated fibers in composite applications, the performance of the final composites reinforced with enzymatically treated fibers also needs to be studied to gain clear insights in the fiber-matrix interactions and which enzyme activities are essential for producing qualitative fibers suitable for impregnation in composites. The assessment of the mechanical properties of the final composites will be important to assign the most promising enzymes or enzyme mixtures.

\section{CONCLUSIONS}

1. Pectate lyase, polygalacturonase, and xylanase are promising enzymes to replace the dew retting process.

2. Chemical characterization of the fibers showed that enzymatic treatments were able to purify fibers. Fibers with cellulose contents of $80 \% \mathrm{w} / \mathrm{w}$ were obtained, compared to green fibers $(64 \% \mathrm{w} / \mathrm{w})$ and dew retted fibers $(72 \% \mathrm{w} / \mathrm{w})$.

3. Separation efficiency is an important factor in the evaluation process of enzymatic treatments. A higher separation efficiency was observed for fibers after Sc $(24 \pm 4 \%)$, PAn $(17 \pm 5 \%)$, and XTl $(21 \pm 4 \%)$ treatment, while green fibers were separated with an $E_{\mathrm{s}}$ value of only $11 \pm 1 \%$. 
4. To reach consistent high-quality fibers in the industry, a more stabilized processing of the material is required. The necessity of a less severe mechanical post-treatment will lead to less fiber damage and higher fiber yield, which can compensate for the costs of the biocatalysts.

\section{ACKNOWLEDGMENTS}

Funding was provided by VLAIO, the Flemish Agency for Innovation and Entrepreneurship (Brussel, Belgium). The authors gratefully thank Elmar Janser from Novozymes and the flax company Verhalle.

\section{REFERENCES CITED}

Adney, B., and Baker, J. (2008). Measurement of Cellulase Activities (NREL/TP-51042628), National Renewable Energy Laboratory, Golden, CO.

Akin, D. E. (2013). "Linen most useful: Perspectives on structure, chemistry and enzymes for retting flax," ISRN Biotechnology 2013, Article ID 186534. DOI: $10.5402 / 2013 / 186534$

Akin, D. E., Condon, B., Sohn, M., Foulk, J. A., Dodd, R. B., and Rigsby, L. L. (2007). "Optimization for enzyme-retting of flax with pectate lyase," Ind. Crop. Prod. 25(2), 136-146. DOI: 10.1016/j.indcrop.2006.08.003

Akin, D. E., Morrison, III, W. H., Gamble, G. R., and Rigsby, L. L. (1997). "Effect of retting enzymes on the structure and composition of flax cell walls," Text. Res. J. 67(4), 279-287. DOI: 10.1177/004051759706700407

Akin, D. E., Gamble, G. R., Morrison, III, W. H., and Rigsby, L. L. (1996). "Chemical and structural analysis of fibre and core tissues from flax," J. Sci. Food Agric.72(2), $155-165$.

Bledzki, A. K., Mamun, A. A., Lucka-Gabor, M., and Gutowski, V. S. (2008). "The effects of acetylation on properties of flax fibre and its polypropylene composites," Express Polym. Lett. 2(6), 413-422. DOI: 10.3144/expresspolymlett.2008.50

Blumenkrantz, N., and Asboe-Hansen, G. (1973). "New method for quantitative determination of uronic acids," Anal. Biochem. 54(2), 484-489. DOI: 10.1016/00032697(73)90377-1

Bos, H. (2004). The Potential of Flax Fibres as Reinforcement for Composite Materials, $\mathrm{Ph}$.D. Dissertation, Technische Universiteit Eindhoven, Eindhoven, Netherlands.

Bourmaud, A., Beaugrand, J., Shah, D. U., Placet, V., and Baley, C. (2018). “Towards the design of high-performance plant fibre composites," Prog. Mater. Sci. 97, 347408. DOI: 10.1016/j.pmatsci.2018.05.005

Cosgrove, D. J. (2005). "Growth of the plant cell wall," Nat. Rev. Mol. Cell Bio. 6, 850861. DOI: $10.1038 / \mathrm{nrm} 1746$

De Prez, J., Van Vuure, A. W., Ivens, J., Aerts, G., and Van de Voorde, I. (2018a). "Evaluation of the extraction efficiency of enzymatically treated flax fibers," in: Advances in Natural Fibre Composites, R. Fangueiro and S. Rana (eds.), Springer International Publishing, Cham, Switzerland, pp. 37-49. DOI: 10.1007/978-3-31964641-1

De Prez, J., Van Vuure, A. W., Ivens, J., Aerts, G., and Van de Voorde, I. (2018b). 
"Enzymatic treatment of flax for use in composites," Biotechnology Reports 20. DOI: 10.1016/j.btre.2018.e00294

Filisetti-Cozzi, T. M. C. C., and Carpita, N. C. (1991). "Measurement of uronic acids without interference from neutral sugars," Anal. Biochem. 197(1), 157-162. DOI: 10.1016/0003-2697(91)90372-Z

George, M., Mussone, P. G., Alemaskin, K., Chae, M., Wolodko, J., and Bressler, D. C. (2016). "Enzymatically treated natural fibres as reinforcing agents for biocomposite material: Mechanical, thermal, and moisture absorption characterization," J. Mater. Sci. 51(5), 2677-2686. DOI: 10.1007/s10853-015-9582-z

Latorre, D. P. (2014). Pectin Remodelling Enzymes of Flax and Their Roles in Fiber Development, Ph.D. Dissertation, University of Alberta, Edmonton, Canada.

Le Duigou, A., Davies, P., and Baley, C. (2011). "Environmental impact analysis of the production of flax fibres to be used as composite material reinforcement," J. Biobased Mater. Bio. 5(1), 153-165. DOI: 10.1166/jbmb.2011.1116

Lin, X., Wu, Z., Zhang, C., Liu, S., and Nie, S. (2018). "Enzymatic pulping of lingocellulosic biomass," Ind. Crop. Prod. 120, 16-24. DOI: 10.1016/j.indcrop.2018.04.033

Miller, G. L. (1959). "Use of dinitrosalicylic acid reagent for determination of reducing sugar," Anal. Chem. 31(3), 426-428. DOI: 10.1021/ac60147a030

Nie, S., Zhang, K., Lin, X., Zhang, C., Yan, D., Liang, H., and Wang, S. (2018).

"Enzymatic pretreatment for the improvement of dispersion and film properties of cellulose nanofibrils," Carbohydr. Polym. 181, 1136-1142. DOI:

10.1016/j.carbpol.2017.11.020

Ramadevi, P., Sampathkumar, D., Srinivasa, C. V., and Bennehalli, B. (2012). "Effect of alkali treatment on water absorption of single cellulosic abaca fiber," BioResources 7(3), 3515-3524. DOI: 10.15376/biores.7.3.3515-3524

Sfiligoj Smole, M., Hribernik, S., Stana Kleinschek, K., and Kreže, T. (2013). "Plant fibres for textile and technical applications," in: Advances in Agrophysical Research, S. Grundas and A. Stepniewski (eds.), London, United Kingdom, pp. 369-398. DOI: $10.5772 / 52372$

Shahid, M., Mohammad, F., Chen, G., Tang, R. C., and Xing, T. (2016). "Enzymatic processing of natural fibres: White biotechnology for sustainable development," Green Chem. 18(8), 2256-2281. DOI: 10.1039/c6gc00201c

Speri, M. (2011). Insights on Microbial and Biochemical Aspects of Retting for Bast Fiber Plant Processing in a Bioreactor, Ph.D. Dissertation, Universita Degli Studi di Verona, Verona, Italy.

Summerscales, J., Dissanayake, N., Virk, A., and Hall, W. (2010). “A review of bast fibres and their composites: Part 1 - Fibres as reinforcements," Compos. Part AAppl. S. 41, 1329-1335. DOI: 10.1016/j.compositesa.2010.06.001

Van Vuure, A. W., Ivens, J., Verpoest, I., Fuentes, C., Osorio, L., Trujillo, E., Hong, N. V., Perremans, D., Bensadoun, F., Hendrickx, K., and Depuydt, D. (2015). "Natural fibre composites: Research highlights of the performance of bamboo, flax and hemp fibres," in: Proceedings of 2nd International Conference on Natural Fibres, R. Fangueiro (ed.), Azores, Portugal, pp. 1-5.

Voragen, A. G. J., Coenen, G. -J., Verhoef, R. P., and Schols, H. A. (2009). "Pectin, a versatile polysaccharide present in plant cell walls," Struct. Chem. 20, 263-275. DOI: 10.1007/s11224-009-9442-z

Wang, L., Liu, X., Zheng, X., and Tian, Y. (2015). "Extraction of pectin from flax fiber 
by chemical means," Int. J. Cloth. Sci. Tech. 27(3), 390-396. DOI: 10.1108/IJCST03-2014-0037

Zhang, J., Henriksson, G., and Johansson, G. (2000). "Polygalacturonase is the key component in enzymatic retting of flax," J. Biotechnol. 81, 85-89.

Zhang, J.-G., Li, Q.-M., Thakur, K., Faisal, S., and Wei, Z.-J. (2017). “A possible watersoluble inducer for synthesis of cellulase in Aspergillus niger," Bioresour. Technol. 226, 262-266. DOI: 10.1016/j.biortech.2016.12.028

Article submitted: November 22, 2018; Peer review completed: January 26, 2019;

Revised version received and accepted: February 10, 2019; Published: February 25, 2019.

DOI: 10.15376/biores.14.2.3012-3030 